\title{
Geochemistry of Some Tertiary and Early Cretaceous Basaltic Exposures around Gulf of Suez (Emphasis on Significance of High Field Strength Elements and their Ratios), Egypt
}

\author{
M. Blasy ${ }^{1}$, S.A. Azzaz ${ }^{2}$, Kh. ALRashidi ${ }^{3}$ \\ ${ }^{1}$ Zagazig University, Faculty of Science, Geology Department, Egypt \\ ${ }^{2}$ Zagazig University, Faculty of Science, Geology Department), Egypt \\ ${ }^{3}$ Kuwait
}

\begin{abstract}
The significance of $\mathrm{Nb}, \mathrm{Zr}, \mathrm{Y}, \mathrm{Ti}$, and REE and the use of their ratios in the Tertiary and Early Cretaceous basalts of Egypt have not been previously noted. The study deals with three basaltic occurrences around Gulf of Suez representing two episodes.Tertiary basalt of Abu Zenima and Ehamer areas show within plate continental /oceanic transition setting and tholeiitic. Early Cretaceous basalt of Abu Darag area are alkaline and within plate continental. In terms of high field strength elements and REE abundances and their ratios, some geochemical constraints has been revealed : 1 - The $\mathrm{Y} / \mathrm{Nb}, \mathrm{Zr} / \mathrm{Y}, \mathrm{Zr} / \mathrm{Nb}$ and LREE/HREE of Tertiary basalts are more comparable but differ than the Early Cretaceous one suggesting two mantle sources;2- $\mathrm{K}_{2} \mathrm{O}, \mathrm{Na} a_{2} \mathrm{O}, \mathrm{Nb}, \mathrm{Zr}, \mathrm{La} / \mathrm{Sm}$ and $\mathrm{LREE} / \mathrm{HREE}$ of the Early Cretaceous basalt are higher than those of Tertiary one suggesting enriched mantle source or small degree of partial melting at greeter depth;3- The chemical weathering has increased $\mathrm{LOI}, \mathrm{MgO}$ and $\mathrm{K} 2 \mathrm{O}$ and decreased $\mathrm{CaO}$ from the marginal part of the Abu Darag basaltic dyke, upper part of Abu Zenima flow and Ehamer dyke, 4- The Early Cretaceous basalt shows a greeter crustal contamination than Tertiary one as indicated from, higher $\mathrm{K}_{2} \mathrm{O} / \mathrm{P}_{2} \mathrm{O}_{5}, \mathrm{Rb}$ and Th and Lower $\mathrm{Zr} / \mathrm{Nb}$, and $\mathrm{TiO}_{2} / \mathrm{P}_{2} \mathrm{O}_{5}$ than Tertiary one.
\end{abstract}

Keywords: basalt, Tertiary, Cretaceous, high field strength elements, REE.

\section{Introduction}

The preliminary review of the Egyptian basaltic rocks indicates that, they have been situated in different tectonic environments and different episodes. The comparing their characteristics with world's basalts, caution must be taken in consideration as the present is the key of the past for Phanerozoic less than $600 \mathrm{Ma}$, i.e.: generation processes of basaltic magma may differ in the rates of formation than the present because the geothermal gradient in past (Archaean) are more steeper, the mantle compositions are changed with geological times and the crust thickness are increased with time[ 1]. The review of different basalt occurrences in Egypt resulted in the following geochemical characteristics, 1-The Tertiary basalts show tholeiitic/alkaline and oceanic/continental transitional characters for most occurrences in the northern part of Egypt [2]. Some Tertiary basalts show alkaline nature (e.g. The Baharyia basalts show alkaline and continental type and those of south Quseir is of low $\mathrm{TiO}_{2}$, alkaline and oceanic/continental setting). As well as the basalts of El Minya are of high $\mathrm{TiO}_{2}$ and continental type .Stratigraphic and/or petrographic similarity of all CairoSuez basalts, Abu Zaabal and Qatrani tends to indicate only one phase of magmatic activity, emplaced along the faults that affected the area during the Oligocene[3]. 2-The Early Cretaceous basalts of Abu Darag areas is continental and alkaline [4], but the Early Triassic basalts of Farsh el Azraq and Wadi Iqna and middle Jurassic basalts of Wadi Abu Natash and Wadi Budra are mildy alkaline [5]. The basalt ages are after [6]. [7] Give geological studies of some basalt in southwest Sinai.

HFSE include Nb, Ta, Y, Zr, P ,Hf, Eu, Lu, Th, La, U, W. Zr is more incompatible than $\mathrm{Ti}$ [8]. Precise determination of these elements and their ratios provide sensitive signatures on characterizing mantle reservoir, crust genesis and subduction magmatism [9]. The present work is aimed to determine the significance of high field strength elements and their ratios for some basaltic rocks of different episodes around Gulf of Suez in Egypt (Fig. 1).

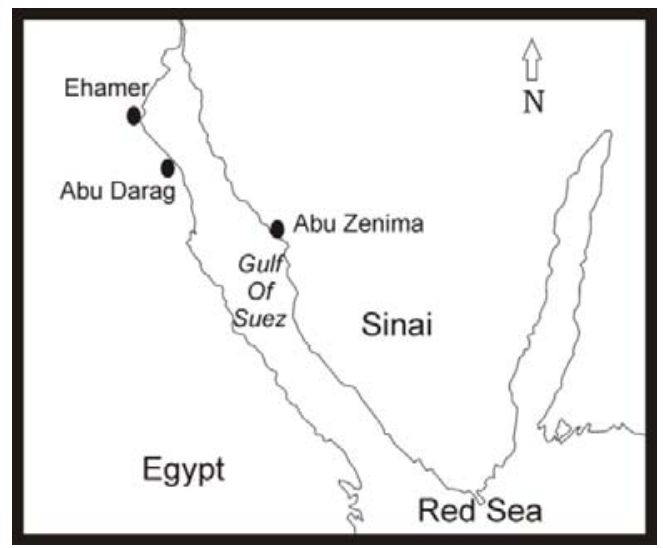

Figure 1: Location map of study basalt occurrences at Abu Zenima, Ehamer, and Abu Darag around Gulf of Suez. 


\section{International Journal of Science and Research (IJSR)}

ISSN (Online): 2319-7064

Index Copernicus Value (2013): 6.14 | Impact Factor (2014): 5.611

\section{Sampling and Analytical methods}

\subsection{Sampling}

More than 30 thin sections have been selected from 300 hand specimens for petrographic investigation.17 representative samples are subjected to XRF method for major and trace elements analysis. The REE of 4 samples are measured using ICP-OES method.

\subsection{X-ray Fluorescence Analysis (XRF)}

The XRF analysis was carried out at Central Laboratories Sector of the Egyptian Mineral Resources Authority, Ministry of Petroleum, Cairo, Egypt. 17 samples are selected for major and trace elements analysis. (5 from Abu Zenima basalt, 6 from Ehamer basalt and 6 from Abu Darag basalt) .The powder $(<74 \mu \mathrm{m})$ samples are subjected to XRF analysis using X-Ray fluorescence equipment PW 2404 with six analyzing crystals. Crystals ( LIF-200 )., ( LIF-220) were used for estimating $\mathrm{Ca}, \mathrm{Fe}, \mathrm{K}, \mathrm{Ti}, \mathrm{Mn}$ and other trace elements from Nickel to Uranium while crystal (TIAP ) was used to determine $\mathrm{Mg}$ and $\mathrm{Na}$. Crystal (Ge) was used for estimating $\mathrm{P}$ and crystal (PET) for determining $\mathrm{Si}$ and $\mathrm{Al}$ and PXL for determining sodium and magnesium. The concentration of the analyzed elements is determined by using software Super Q and Semi Q programs with accuracy $99.99 \%$ and confidence limit $96.7 \%$. The estimation of the major and trace elements were done as powder pellets (Pellets method) which were prepared by pressing the powder of the sample in Aluminum Cup using Herzog presser and 10 ton pressure. On the other hand using fusion method in platinum crucible (Bead method) gives better results for light elements measurements, but owing to presence of phosphorus in phosphate and sulfur in sulphides in the sample which led to corrosion in platinum crucible, we used the pellet method as mentioned above.

\subsection{ICP-OES Analysis}

The REE analysis of the four basalt samples were performed using a simultaneous inductively coupled plasma emission spectrometer (720 ICP -OES) (Agilent technologies).Sample powders $(0.5 \mathrm{gm}$.) were sealed in a Teflon cup and digested in $5 \mathrm{ml}$ nitric acid, $3 \mathrm{ml}$ per chloric acid and $15 \mathrm{ml}$ hydrofluoric acid and put in hot plate for 4 hours till complete digestion, the add $5 \mathrm{ml}$ of hydrochloric acid to give clear soluble solution, The techniques used (XRD and ICPOES) are performed at Central Laboratories Sector of the Egyptian Mineral Resources Authority, Ministry of petroleum, Cairo ,Egypt.

\section{Field Geology}

\subsection{Abu Zenima basaltic outcrop}

The basaltic rocks near Abu Zenima city (Lat. $29^{\circ} 4 ` 10^{\prime \prime} \mathrm{N}$ and Long. $\left.33^{\circ} 5^{`} 50^{\prime \prime} \mathrm{E}\right)$ occurs as an inclined sheet $(20 \mathrm{~m}$ thick) (Fig.1), marked by three colors; black for the lower part, brownish for the middle and greenish for the top of the sheet due to the oxidation, carbonation and hydration of sulphide and oxide minerals. The upper part is highly vesicular. The vesicles are filled with calcite, epidote and quartz and found as green amygdales reaching in size up to 2 $\mathrm{cm}$ (Fig.2c). $\mathrm{Cu}$ sulphate and $\mathrm{Cu}$ carbonate is responsible for the green coloration of the upper part of the basaltic sheet. Iron hydroxide stained the middle part of the basaltic sheet by brownish color. The bottom part of the sheet is more or less fresh. Columnar joints are found, and partly weathered giving rounded blokes present as Paranoiac statues carved into the mountain (Fig 2d). The above description indicates that the basaltic sheet of Abu Zenima is subareal flow, covered unconformabley by conglomerate beds of Nuchal Formation, and composed essentially of rounded fragments of limestone, sandstones, and cherts (Fig.2a), belonging to Miocene age. They are neither stained by reddish colors nor thermally affected. The basaltic sheet is underlain by marly sand bed of Eocene age with a small outcrop of a conglomerate bed of upper Eocene (the upper bed of Typa Formation) and stained by reddish and grayish colors (Fig.2b). The conglomerates are composed of reworked rounded polders of limestone. The polders are hard due to thermal effect and rich in Numulites and Discocyclina with microcrystalline matrix. [10] Write that, on the Sinai margin in the type section of Abu Zenima, the red beds are capped by a basalt flow, K/Ar dated at $22 \mathrm{Ma}$ and Abu Zenima area comprises two main events of basaltic intrusions). i) Middle

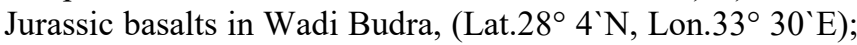
and, ii) Oligocene-Miocene rocks from Wadi Nukhul, (Lat. $29^{\circ} 02^{`} \mathrm{~N}$, Long. $33^{\circ} 16^{`} \mathrm{E}$ ).

\subsection{Ehamer basaltic outcrop}

The basaltic rocks at Ehamer area, near Ain El Sokhna (Lat.29 $34^{\circ} \mathrm{N}$ and. $32^{\circ} 22^{\circ} \mathrm{E}$ ) is exposed as large mass $(\sim 300 \mathrm{~m} 2)$ or plug, intruding the limestone strata. The rocks are black and fine- to medium grained. Cuboidal joints are pronounced and evolved to spheroidal blokes with weathered surface giving onion structure (Fig.2g). Rounded white xenoliths of carbonate minerals are found through the basalt plug (Fig.2f). The plug is dissected by thin basaltic dyke $(\sim 1$ $\mathrm{m}$ thick)), found as black ridge (Fig.2e). The country limestone is thermally metamorphosed to marble (calcitic type as determined by XRD and DTA analysis).

\subsection{Abu Darag basaltic outcrop}

The basaltic rocks at Abu Darag area (Lat.29 $24^{\prime} \mathrm{N}$ and Long. $\left.32^{\circ} \quad 30^{\circ} \mathrm{E}\right)$ are found as thick dyke ( $\sim 10 \mathrm{~m}$ width), trending northwest and intruding sandstone beds of upper Carboniferous -lower Permian, for about $300 \mathrm{~m}$ length .It is exposed as high ridge ( $\sim 12 \mathrm{~m}$ height) (Fig.2 h).Their sides and country rocks are covered by black fragments of basalts. The intruded sandstone is stained by reddish brown color of iron oxides and weakly affected by thermal metamorphism. The basalt dyke margins are very fine -grained and vesicular. 


\section{International Journal of Science and Research (IJSR) \\ ISSN (Online): 2319-7064}

Index Copernicus Value (2013): 6.14 $\mid$ Impact Factor (2014): 5.611

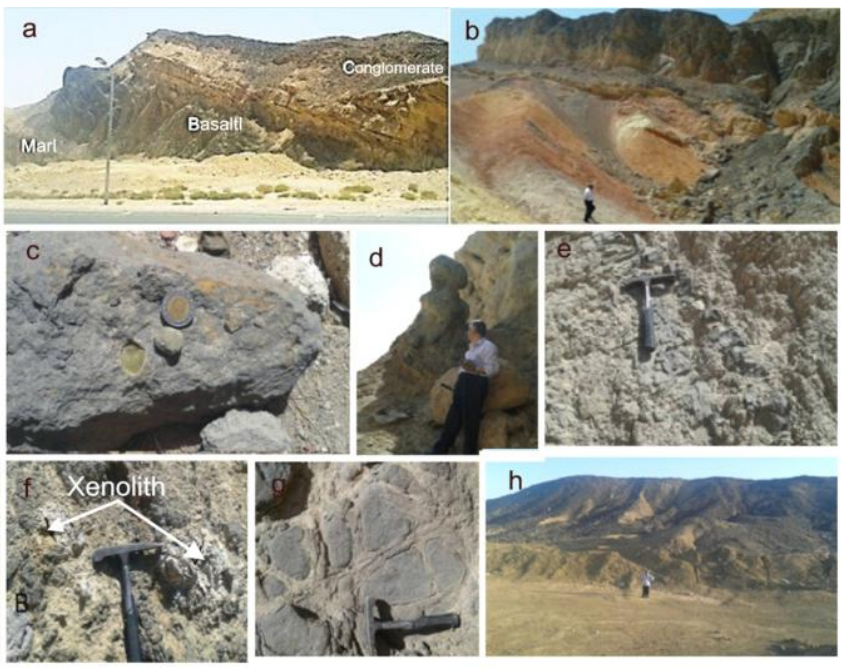

Figure 2: Field photos of, a) Abu Zenima basaltic sheet covered by conglomerate bed; b) Stained marly sand underlie basalt sheet; c) Rounded amygdale in basalt; d) Weathered basalt blocks as Paranoiac statues carved into the mountain;

e) Ehamer plug dissected by thin basaltic dyke; f) White carbonate xenoliths in Ehamer basalt plug; g) Onion structure of Ehamer basalt showing spheroidal plucks; h) Thick basalt dyke at Abu Darag area.

\section{Petrography}

\subsection{Abu Zenima basaltic sheet}

The basalt rocks are composed essentially of plagioclase, pyroxene and olivine .Iron oxide is common accessory $(\sim 2 \%)$ but iddengesite, calcite and hydrous iron oxide are secondary minerals. High temperature $\mathrm{SiO}_{2}$ polymorph (crystobalite )is determined by XRD. The rocks of the upper parts of the sheet are marked by numerous vugs and vesicles filled by quartz, calcite and cupper minerals may be cu sulphate and/ or $\mathrm{Cu}$ carbonates, found as green patches in layering as a result of deposition from solution (Fig.3e, f). Some calcite filling vesicles encloses euhedral opaque crystal of columbite? (Fig. 3a, b).Plagioclase is found as lathes up to 0 $.5 \mathrm{~mm}$ length, exhibiting normal and oscillatory zoning (Fig.3g). Lamellar and compound alpite- carlsbad twinning are found. Plagioclase phenocrysts (An 50\%) are common and some crystals penetrated by green patches of sulphate mineral along the twin planes and cracking .Most plagioclase phenocrysts are rimmed by thin mantle of alpite. Olivine crystals are common as phenocrysts. The olivine phenocrysts in the upper parts of the sheet are smaller in size, strongly altered to red brown patches of iddengesite (Fig. 3c). Olivine crystals in the middle part of the basaltic sheet is weakly altered (Fig.3h, i) while that of the lower part is mostly fresh (Fig, 3j). Pyroxene is of diopside and augite in composition. Some show simple twinning (Fig.3k), and eight sided crystal, sometimes found in aggregate forming a glomeroporphyretic texture (Fig.3 1). Pyroxene crystals show pale brown tintswith two sets of cleavage at $90^{\circ}$ and enclose lathes of plagioclase in ophitic fashion (Fig.3d).Iron oxides are common, as black anhedral to subhedral grains up to $0.5 \mathrm{~mm}$ across. Chemical weathering resulted in producing solution rich in $\mathrm{Fe}-\mathrm{Mn}$, and $\mathrm{Ca}$. Such solutions favored the leaching of $\mathrm{Nb}$ from the host basalt and redeposited in vugs and vesicles giving amygdales of calcite enclosing some euhedral crystals of columbite. [11], write that, "The hydrothermal fluids are inferred to have been $\mathrm{F}$-and $\mathrm{CO}_{2}$-rich with variable levels of $\mathrm{Ca}$ activity, and with $\mathrm{fO}_{2}$ mainly between nickel-nickel oxide and magnetite -hematite buffers. This occurrence represents a new genesis for a columbite -group mineral. Columbite $\left\{(\mathrm{Fe}, \mathrm{Mn},)(\mathrm{Nb}, \mathrm{Ta})_{2} \mathrm{O}_{6}.\right\}$ is a typical product of the hydrothermal alteration of pyrochlore in many carbonatite, including calcitic and alkali carbonatite and also basaltic melts extract both $\mathrm{Nb}$ and $\mathrm{Ta}$ elements.

\subsection{Ehamer}

\subsubsection{Basaltic Plug}

The rocks are black to dark brownish grey, hard, and medium grained. They are composed essentially of olivine, pyroxene and plagioclase. Iron oxide as accessory and iddengesite is secondary .Olivine is found as small rounded grains and as coarse euhedral crystals up to $0.1 \mathrm{~mm}$ across. Olivine forms about $10 \%$ of the bulk composition of the rock. Pyroxene is common about $40 \%$ and found as anhedral and euhedral grains with pale brownish tint. The extinction angles are about $35^{\circ}$. The crystals are weekly pleochroic and show cleavage in two directions at right angles .Pyroxene is of augite type as determined by XRD. Most grains enclose some plagioclase crystals in ophitic fashion (Fig.4c, d, e). Zoning is common. The core is calcic and the outer zones show oscillatory zonation. Plagioclase is found as tabular crystals up to $0.2 \mathrm{~mm}$ width and $5 \mathrm{~mm}$ length(Fig,4a), forming about $45 \%$. They form with pyroxene and olivine an interganular texture (Fig.4b)). Most grains are fresh and show lamellar and compound albite-carlsbad twinning (Fig.4a). The extinction angle gives anorthite content of about $50 \%$ ( i.e. anorthite and labradorite composition as indicated by XRD. The intruded country rock is limestone, thermally metamorphosed to calcite marble. The latter is hard, grey in color, and medium grained. It is composed of calcite grains .They found in mosaic aggregate as a result of thermal metamorphism by basaltic plug. Carbonate xenoliths within the basaltic plug are white, fine grained, massive and soft. They are composed essentially of fine grains (less than $0.01 \mathrm{~mm}$ ) with some rounded crystals of calcite (up to $1 \mathrm{~mm}$ across).

\subsubsection{Phase (2) basaltic dyke (dissecting basaltic plug)}

The rocks are black, hard and very fine grained and composed of olivine, pyroxene and plagioclase as essential mineral. Iron oxide is accessory. Iddengesite, chlorite, talc and antigorite are secondary. Plagioclase of the groundmass is very fine laths $<0.01 \mathrm{~mm}$.plagioclase phenocrysts found as lathes $<0.1 \mathrm{~mm}$ in length. Some show zoning and compound twinning (Fig.4f, g) Pyroxene is found as phenocrysts up to $1 \mathrm{~mm}$ and in aggregate forming glomeroporpheritric texture. The grains show two sets of cleavage and week pleochroism from colorless to pale brownish yellow. Some pyroxene crystals show simple twinning and hourglass zoning. Olivine is found as euhedral phenocrysts, partly altered to talc, antigorite and iddengesite minerals as pseudomorph grains.

\section{Volume 5 Issue 1 January 2016}




\section{International Journal of Science and Research (IJSR) \\ ISSN (Online): 2319-7064}

Index Copernicus Value (2013): 6.14 | Impact Factor (2014): 5.611

\subsection{Abu Darag basaltic dyke}

The basaltic rocks of Abu Darag dyke show some zonation (core and margin rocks). The core is hard, black, fine grained and massive. It is composed of olivine phenocrysts (up to 0.5 $\mathrm{mm}$ across) as fresh euhedral crystals. Some grains shows alteration to chlorite, antigorite and iddengesite along $\mathrm{Y}$ cracks (Fig.4h, i) .The olivine grains are set in a very fine grained groundmass of plagioclase laths $<0.01 \mathrm{~mm}$ ) and granules of iron oxide and pyroxene (Fig.4h, i).The plagioclase and pyroxene are of anorthite and augite respectively as determined by XRD .Some quartz xenoliths are recorded and surrounded by reaction zone of pyroxene granules (Fig. $4 \mathrm{j}, \mathrm{k}$ ). The marginal basaltic rocks are brownish black in color and vugy or vesiculated. Vugs or vesicles are empty and sometimes filled with calcite and /or quartz. Olivine is found as small grains, strongly altered to iddengesite and antigorite fibers set in a very fine to glassy groundmass. The latter is composed of pyroxene, fine lathe of plagioclase and iron oxides. Quartz xenolith in the marginal rocks do not show reaction zones (Fig.41).The country rocks are hard sandstone, composed of clear grains of rounded quartz cemented by clear calcite crystal and stained by reddish colors of iron oxides, suggesting weak thermal metamorphism.
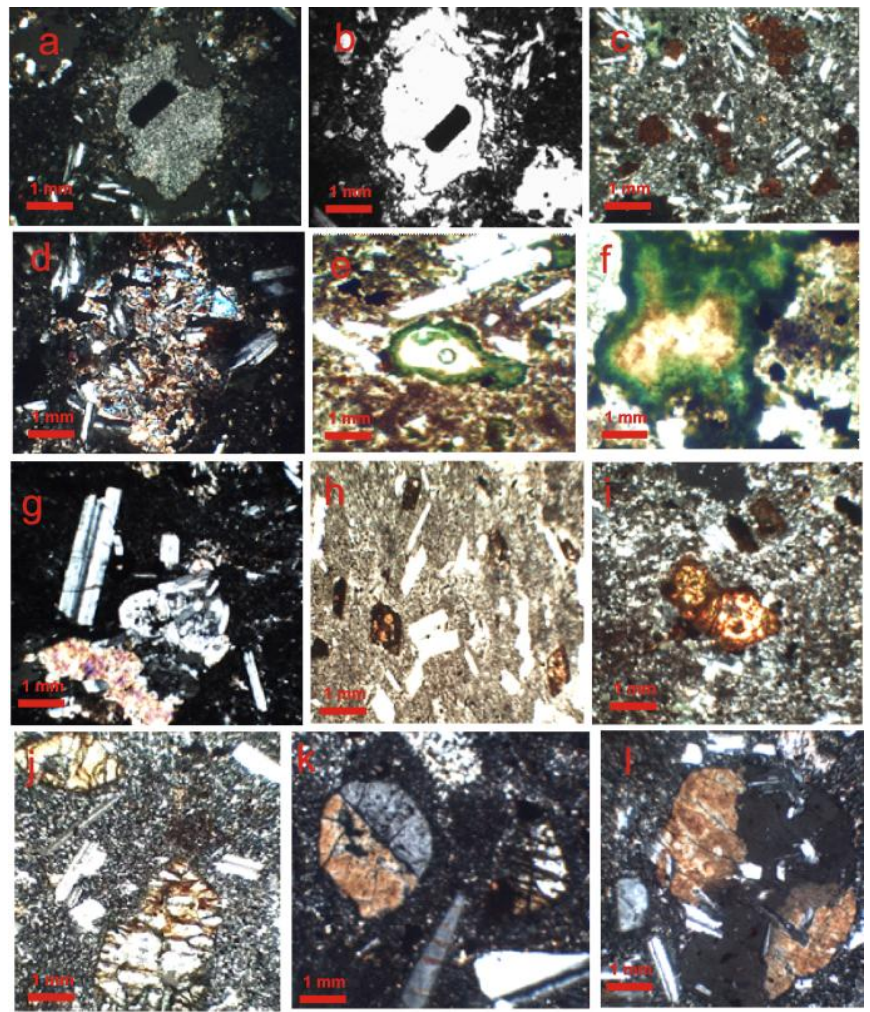

Figure 1: Photomicrographs of the study basaltic rocks of

Abu Zenima, showing, a) A columbite crystal hosted in calcite filling vesicle under crossed polars; b) The same photo under ppl ; c) Olivine crystal, completely altered to iddingesite; d) Augite phenocryst sieved by plagioclase lathes

in ophitic fashion; e and f ) Vesicles filled by zoned hydrothermal minerals of calcite core , $\mathrm{Cu}$-sulphate and $\mathrm{Fe}$ -oxide mantle; g) Plagioclase phenocryst; h and i )

Phenocrysts of olivine partly altered to iddingesite from the middle part of the basalt sheet ; j) Fresh olivine phenocryst from the lower part of the basalt sheet ; k) Augite phenocryst ,showing simple twinning ;l) Augite in aggregate giving glomeropheric texture.
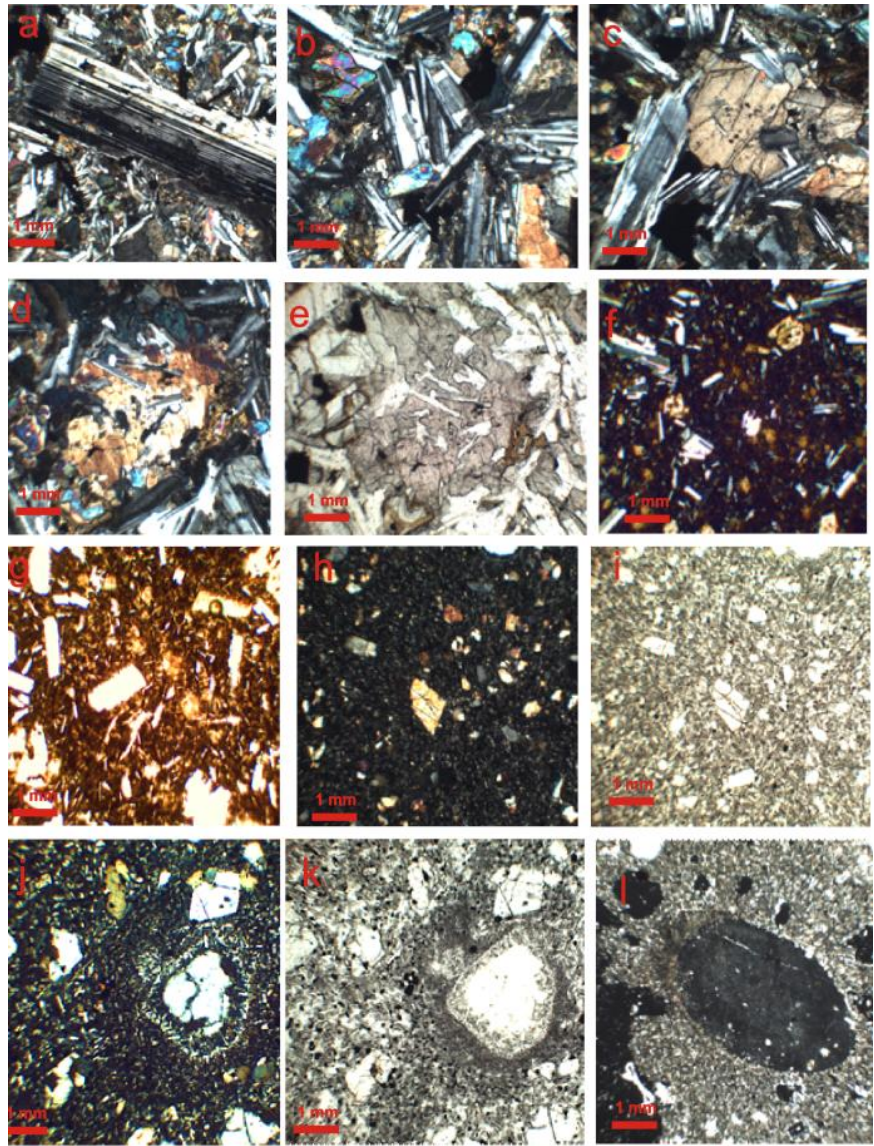

Figure 4: Photomicrographs of Ehamer and Abu Darag basalts ,a) Plgioclase phenocrysts in basalt of Ehamer plug ; b) Intergranular texture from Ehamer basalt plug ; c, d ,e) Augite phenocrysts enclosing plagioclase in ophitic texture from Ehamer basaltic plug ; f, g )Fine grained porphyritic basalt with phenocrysts of plagioclase, olivine and pyroxene from the basalt dyke dissecting Ehamer basalt plug ; h,i ) Phenocrysts of olivine from Abu Darag basalt under C.N. and PPL.; J,K ) Quartz xenoliths from the core of Abu Darag

basalt dyke ,showing reaction zone ; 1) Rounded quartz xenolith from the margin of Abu Darag basalt dyke without reaction zone.

\section{Geochemistry}

The major and trace elements analysis of 17 representative samples is presented in Table (1) together with REE analysis for 4 samples (Table 2).

\subsection{Geochemistry of Abu Zenima basalts}

The chemical analysis of the three parts of basaltic sheet is shown in Table 1. The basalts of the upper part are enriched in $\mathrm{SiO}_{2}, \mathrm{~K}_{2} \mathrm{O}$, LOI and $\mathrm{Rb}$. The lower part of the basaltic sheet has high abundances of $\mathrm{Al}_{2} \mathrm{O}_{3}, \mathrm{Na}_{2} \mathrm{O}, \mathrm{Cr}, \mathrm{Ba}$ and $\mathrm{Th}$. 


\section{International Journal of Science and Research (IJSR) \\ ISSN (Online): 2319-7064 \\ Index Copernicus Value (2013): 6.14 | Impact Factor (2014): 5.611}

Table 1: Geochemical analysis of some Tertiary basalts at Abu Zenima and Ehamer and Early Cretaceous basalts at Abu Darag areas exposed around Gulf of Suez, Egypt

\begin{tabular}{|c|c|c|c|c|c|c|c|c|c|c|c|c|c|c|c|c|c|}
\hline ** samples & 1 & 2 & 3 & 4 & 5 & 6 & 7 & 8 & 9 & 10 & 11 & 12 & 13 & 14 & 15 & 16 & 17 \\
\hline \multicolumn{18}{|c|}{ Major Oxides (Wt \%) } \\
\hline & 8.34 & 50.1 & 47.7 & 46.15 & 48.1 & 47.89 & 49.23 & 50.67 & 44.86 & 46.8 & 48.63 & 43.55 & 45 & 47.39 & 45.85 & 47.5 & 49.44 \\
\hline $\mathrm{TiO}_{2}$ & 27 & 2.1 & 2.48 & .71 & 2.5 & 2.74 & 2.51 & 2.9 & 3.17 & 2.9 & 2.76 & 2.25 & 2.06 & 1.92 & 2.52 & 2.32 & 2.11 \\
\hline $\mathrm{Al}_{2} \mathrm{O}_{3}$ & .36 & 11.2 & 13.61 & 3.85 & 13.7 & 14.63 & 14.5 & 14.33 & 12.28 & 12 & 11.74 & 12.66 & 12.6 & 12.33 & 12.16 & 11.9 & 11.72 \\
\hline $\mathrm{O}_{3}$ & .21 & 13.1 & 2.86 & 2.98 & 13.1 & 13.22 & 13.06 & 12.92 & 14.66 & 14.5 & 14.22 & 13.97 & 13.9 & 13.16 & 10.25 & 10.06 & 9.87 \\
\hline & 02 & 0.01 & 0.01 & 0.03 & 0.02 & 0.04 & 0.03 & 0.02 & 0.03 & 0.02 & 0.01 & 0.04 & .03 & 0.02 & 0.03 & 0.02 & 0.01 \\
\hline & 23 & 6.26 & 6.19 & & 6.21 & .73 & .56 & & & 8.8 & .55 & .95 & 9.7 & .45 & 11.46 & 11.26 & 11.02 \\
\hline & .75 & 11.4 & 12.1 & .25 & 2.65 & 0.52 & 0.39 & 0.21 & & 9.6 & .39 & 11.02 & 10.9 & 0.62 & 9.2 & 8.97 & 8.74 \\
\hline & 89 & 1.71 & 1.92 & & \begin{tabular}{|l|}
1.98 \\
\end{tabular} & 2.18 & 1.96 & 1.87 & 1.71 & 1.52 & 1.27 & 2.72 & 2.56 & 2.36 & 2.77 & 2.7 & 2.49 \\
\hline & & 1.74 & 0.63 & & 0.56 & 87 & .78 & & & .69 & 0.48 & 1.51 & 1.13 & 1.12 & 1.42 & 1.21 & 1.02 \\
\hline & 41 & 0.25 & 0.86 & & 0.36 & 48 & 0.38 & & & .28 & 0.16 & .59 & 0.53 & 0.31 & 0.5 & 0.4 & 0.29 \\
\hline & 85 & 2.06 & 0.75 & & 0.78 & 45 & 0.26 & & 2.98 & 2.74 & 2.51 & 1.52 & 1.2 & 1.03 & 3.58 & 3.27 & 3.03 \\
\hline & 3.31 & 98.18 & \begin{tabular}{|l|}
98.47 \\
\end{tabular} & 98.89 & \begin{tabular}{|l|}
99.38 \\
\end{tabular} & \begin{tabular}{|l|}
98.84 \\
\end{tabular} & \begin{tabular}{|l|}
98.85 \\
\end{tabular} & \begin{tabular}{|l|}
99.74 \\
\end{tabular} & \begin{tabular}{|l|}
98.76 \\
\end{tabular} & 99.14 & 99.23 & 98.23 & 98.45 & 98.57 & 98.29 & 98.38 & 98.71 \\
\hline \multicolumn{18}{|c|}{ Trace Elements $(\mathrm{ppm})$ and chemical ratios } \\
\hline $\mathrm{V}$ & 5.5 & 363.8 & 401.8 & 88.2 & 371 & 381.7 & 338.8 & 379.5 & 443.7 & 469.8 & 439.8 & 275.5 & 281.5 & 278.1 & 326.2 & 319 & 321.5 \\
\hline & 3.6 & 104.1 & \begin{tabular}{|l|l|}
152.2 \\
\end{tabular} & & 479 & 109.8 & 81.7 & & & 92.6 & 92.9 & 587 & 667 & 576.9 & 270.8 & 57 & 562.7 \\
\hline & 5.7 & 46.5 & 154 & 155.4 & 57.4 & 55.7 & 52.1 & 3.4 & & 56.4 & 65.1 & 331.9 & 332 & 330.5 & 421.1 & 414 & 417.6 \\
\hline & .1 & 25.1 & \begin{tabular}{|l|}
45.69 \\
\end{tabular} & & 43 & 7.4 & 4.9 & 7 & & 9.7 & 76.5 & 7.7 & 4.2 & 5.8 & 39.9 & 3.3 & 86.2 \\
\hline & 3.9 & 138.9 & \begin{tabular}{|l|}
150.3 \\
\end{tabular} & 149.7 & 136 & 193.5 & \begin{tabular}{|l|}
194.8 \\
\end{tabular} & 190.8 & \begin{tabular}{|l|}
108.3 \\
\end{tabular} & 7.8 & 106.2 & 127.8 & 128 & 128.3 & 142.9 & 136 & 138.4 \\
\hline & & \begin{tabular}{|l|}
57.5 \\
\end{tabular} & \begin{tabular}{|l|}
66.01 \\
\end{tabular} & & 64 & 63.4 & 57.8 & & & 0.2 & 68.8 & 5.5 & 2.8 & 4.1 & 8.4 & & 65.9 \\
\hline & 1.2 & 24.4 & 5.05 & & 25 & & 25.8 & & & & 25.5 & 3.6 & 3.4 & 2.5 & 24.6 & & 24.8 \\
\hline & & 31.8 & \begin{tabular}{|l|}
19.13 \\
\end{tabular} & & \begin{tabular}{|l|}
18 \\
\end{tabular} & 22.6 & \begin{tabular}{|l|}
21.5 \\
\end{tabular} & & & 23.9 & 21.4 & 35.9 & 35.1 & 34.7 & $\mathrm{sJ}$ & 34 & 34.3 \\
\hline $\mathrm{Sr}$ & 06.6 & 616 & \begin{tabular}{|l|}
670.6 \\
\end{tabular} & \begin{tabular}{|l|}
669.1 \\
\end{tabular} & \begin{tabular}{|l|}
530.7 \\
\end{tabular} & 566.3 & \begin{tabular}{|l|}
530.7 \\
\end{tabular} & \begin{tabular}{|l|}
595.8 \\
\end{tabular} & \begin{tabular}{|l|}
584.8 \\
\end{tabular} & 564 & 577.2 & 728.7 & 717 & 721.2 & 735.4 & 706 & 719.7 \\
\hline $\mathrm{Y}$ & & \begin{tabular}{|l|}
33 \\
\end{tabular} & \begin{tabular}{|l|}
31.91 \\
\end{tabular} & & \begin{tabular}{|l|}
30.3 \\
\end{tabular} & & & & & 34 & 29.7 & 29 & 28 & 28.3 & 31.4 & 29 & 30.2 \\
\hline $\mathrm{Zr}$ & 97.9 & 219.2 & \begin{tabular}{|l|}
237.7 \\
\end{tabular} & 237.1 & 230 & 224.2 & \begin{tabular}{|l|}
206.4 \\
\end{tabular} & \begin{tabular}{|l|}
220.8 \\
\end{tabular} & \begin{tabular}{|l|}
237.5 \\
\end{tabular} & 248 & 234.3 & 259.8 & 255 & 256.4 & 272.5 & 260 & 265.5 \\
\hline & & \begin{tabular}{|l|}
19.2 \\
\end{tabular} & & & 20 & & & & & 21.4 & 22.8 & 45.7 & 44.5 & 46.2 & 49 & .4 & 47.8 \\
\hline $\mathrm{Ba}$ & 37.4 & 638 & 763.4 & & 1238 & 683.8 & \begin{tabular}{|l|}
678.3 \\
\end{tabular} & \begin{tabular}{|l|}
723.5 \\
\end{tabular} & 578 & 646 & 589.4 & 718.2 & 773 & 745.8 & 792.6 & 23 & 810.4 \\
\hline & 8.6 & 16.4 & \begin{tabular}{|l|}
20.27 \\
\end{tabular} & & 10.2 & & \begin{tabular}{|l|}
13.4 \\
\end{tabular} & \begin{tabular}{|l|}
15.8 \\
\end{tabular} & & 22 & \begin{tabular}{c|}
16.3 \\
\end{tabular} & 42.9 & 28.4 & 34.6 & 45.6 & 50.6 & 47.7 \\
\hline $\mathrm{Ta}$ & 2.4 & 2.3 & \begin{tabular}{|l|}
2.4 \\
\end{tabular} & & 2.3 & 2.4 & 2.2 & 2.2 & & 2.4 & 2.2 & 2.6 & 2.7 & 2.5 & 2.4 & 2.3 & 2.3 \\
\hline & & & & & 3 & & 10.5 & & & & 4.1 & 0.1 & 4.5 & 5.8 & 5.6 & 5 & 5.4 \\
\hline & 9 & 12.7 & 10.5 & 11. & 16.2 & 10.5 & 11.2 & 87 & 10.4 & 11.1 & 8.9 & 21.2 & 15.2 & 18.3 & 24.5 & 15 & 19.8 \\
\hline & 1.87 & 1.72 & 1.56 & & 1.52 & & 1.57 & & & & 1.3 & 0.63 & 0.63 & 0.61 & 0.64 & 0.64 & 0.63 \\
\hline $\mathrm{Zr} / \mathrm{Y}$ & 6.42 & 6.64 & 7.45 & & 7.59 & 6.75 & 7.14 & 7.03 & 7.29 & 7.29 & 7.89 & 8.96 & 9.11 & 9.06 & 8.68 & 8.97 & 8.79 \\
\hline $\mathrm{Zr} / \mathrm{Nb}$ & 12.02 & 11.42 & 11.6 & 11.24 & 11.5 & 10.94 & 11.22 & 10.22 & 10.94 & 11.59 & 10.28 & 5.68 & 5.73 & 5.55 & 5.56 & 5.73 & 5.55 \\
\hline & 2.12 & 2.09 & 2.08 & & 2.11 & 1.96 & 1.99 & & & 1.65 & 1.66 & 1.4 & 1.43 & 1.39 & 0.89 & 0.89 & 0.9 \\
\hline & 4.63 & 6.96 & 0.73 & & 1.56 & 1.81 & 2.05 & 2.15 & 2.38 & 2.46 & 3 & 2.56 & 2.13 & 3.61 & 2.84 & 3.025 & 3.52 \\
\hline $\mathrm{TiO}_{2} / \mathrm{P}_{2} \mathrm{O}_{5}$ & 5.54 & 8.4 & 2.88 & 5.77 & 6.94 & 5.71 & 6.61 & 10.74 & 8.13 & 10.36 & 17.25 & 3.81 & 3.89 & 6.19 & 5.04 & 5.8 & 7.28 \\
\hline
\end{tabular}

**1, 2 top Abu Zenima, 3, 4 middle Zenima, 5 bottom Zenima, 6, 7, 8 Plug Ehamer, 9,,10, 11Ehamer dyke 12, 13, 14 core Abu Darag and 15, 16, 17 Margin Abu Darag.

Table 2: Rare earth elements analysis of some Tertiary basalts at Abu Zenima (Z) and Ehamer (E) and Early Cretaceous basalts at Abu Darag (D) areas exposed around Gulf of Suez, Egypt

\begin{tabular}{|c|c|c|c|c|}
\hline & \multicolumn{2}{|c|}{ Z middle } & E plug & \multicolumn{2}{c|}{ D core } & D margin \\
\hline LREE & \multicolumn{2}{|c|}{ Tertiary basalt } & \multicolumn{2}{|c|}{ Early Cretaceous basalt } \\
\hline $\mathrm{Ce}$ & 30.1 & 30 & 43 & 42.8 \\
\hline $\mathrm{Eu}$ & 2.3 & 2.4 & - & - \\
\hline $\mathrm{Gd}$ & 13.1 & 14.5 & 11 & 10.6 \\
\hline $\mathrm{Nd}$ & 203 & 214 & 138 & 137 \\
\hline $\mathrm{Pr}$ & 13.5 & 12.5 & 12 & 11.4 \\
\hline $\mathrm{Sm}$ & 3.9 & 4.1 & 1 & 1.8 \\
\hline$\Sigma \mathrm{LREE}$ & 265.9 & 277.5 & 205 & 203.6 \\
\hline $\mathrm{Tb}$ & 0.55 & 0.95 & 0.8 & 0.78 \\
\hline $\mathrm{Yb}$ & 3 & 3.6 & - & - \\
\hline $\mathrm{Dy}$ & 2.6 & 2.5 & 1.3 & 1.2 \\
\hline $\mathrm{Er}$ & 6.6 & 7.2 & 2 & 2.1 \\
\hline$\Sigma \mathrm{HREE}$ & 12.75 & 14.25 & 4.1 & 4.08 \\
\hline $\mathrm{LREE} / \mathrm{HREE}$ & 20.85 & 19.47 & 50 & 49.9 \\
\hline $\mathrm{La} / \mathrm{Sm}$ & 5.2 & 10.6 & 28.4 & 28.1 \\
\hline
\end{tabular}

The middle part of the sheet has high concentrations of $\mathrm{V}$, $\mathrm{Ni}, \mathrm{Co}, \mathrm{Zr}, \mathrm{Cu}, \mathrm{TiO}_{2}, \mathrm{Zn}$ and $\mathrm{Pb}$. The variation of elements concentrations in the different parts of the basaltic sheet reflects clearly the effect of fractionation, weathering, contamination and rate of cooling. The upper part of the flow is rabidly cooled and form glassy skin preventing the escaping of the gasses and consequently resulted in large vesicles (filled with secondary minerals, giving amygdales). The upper part has been partly weathered together with the glassy skin. Glassy basaltic part represents the original basaltic melt .The chemical weathering was so strong or active as the rock of the upper part was vesicular. These processes resulted in increasing the water content, hydrous iron oxides and leaching of some mobile elements as $\mathrm{Ca}, \mathrm{Mn}$, $\mathrm{Cu}, \mathrm{Pb}$ and $\mathrm{Ba}$. The fractionation is reflected in increasing the concentration of $\mathrm{SiO}_{2}$ and $\mathrm{Fe}_{2} \mathrm{O}_{3}$ in the upper part of flow .The lower part of the basaltic sheet was cooled rabidly and the melt become relatively viscous inhibiting olivine to settle

\section{Volume 5 Issue 1 January 2016}




\section{International Journal of Science and Research (IJSR) \\ ISSN (Online): 2319-7064}

Index Copernicus Value (2013): 6.14 | Impact Factor (2014): 5.611

down to the bottom. This is resulted in concentration of the olivine minerals in the middle zone. Therefore the abundances of $\mathrm{Ni}$ are high in this zone as this element is highly partition in the olivine. The enrichment of $\mathrm{Fe}_{2} \mathrm{O}_{3}$ and $\mathrm{Cr}$ in the lower zone may be due to the settling down of the heavy minerals as chromite and /or magnetite when the melt was mobile in the early stage of flow. The abundances of $\mathrm{Zr}$, $\mathrm{Nb}, \mathrm{Y}$ and $\mathrm{Ta}$ in the three zones are more or less similar due to their incompatibility (i.e. not affected neither by fractionation nor weathering). The middle zone is rich in $\mathrm{Cu}$, $\mathrm{Pb}$, and $\mathrm{Zn}$. This may be attributed to the process of secondary enrichment of sulphides. The chemical weathering of the upper part of the Abu Zenima basalt flow has added $\mathrm{MgO}$, LOI and $\mathrm{K}_{2} \mathrm{O}$ and removed $\mathrm{CaO}$, resulting in strongly modified major element compositions. However, the more immobile trace elements remain largely unaltered (Table 1).

\subsection{Geochemistry of Ehamer basaltic plug and basaltic dykes}

The basalt of Ehamer is found as plug, dissected by thin basaltic dykes. The chemical analysis of both phases indicate that , the plug is marked by high concentration of $\mathrm{SiO}_{2}$, $\mathrm{Al}_{2} \mathrm{O}_{3}, \mathrm{CaO}, \mathrm{Na}_{2} \mathrm{O}, \mathrm{Zn}$, while the basaltic dyke is rich in $\mathrm{TiO}_{2}$, $\mathrm{Fe}_{2} \mathrm{O}_{3}, \mathrm{MgO}$, LOI , $\mathrm{V}, \mathrm{Ni}, \mathrm{Co}$ and $\mathrm{Zr}$. The two phases has the same element ratios ( $\mathrm{Y} / \mathrm{Nb}, \mathrm{Zr} / \mathrm{Y}, \mathrm{Zr} / \mathrm{Nb}$ ) suggesting the same mantle source in spite of the differences in the degree of fractionation of both phases. The dyke was intruded through the deep seated joints dissecting the basaltic plug as a result of shrinkage after solidification. Then the basaltic rocks of dyke may be affected by action of meteoric water penetrated through the margins and micro joints. This resulted in high concentration of hydrous minerals and increasing in LOI( Table 1).The basaltic rocks of dyke represent weak fractionation as compared with the host basaltic plug indicated from the high concentration of $\mathrm{Ni}, \mathrm{TiO}_{2}, \mathrm{~V}, \mathrm{Cr}$ and $\mathrm{MgO}$ and lower abundances in $\mathrm{K}_{2} \mathrm{O}$ and $\mathrm{Si}_{2} \mathrm{O}$. The chemical weathering has added $\mathrm{MgO}$ and $\mathrm{K}_{2} \mathrm{O}$ and removed $\mathrm{CaO}$ from basaltic dike resulting in strongly modified major element compositions. However, the more immobile trace elements remain largely unaltered (Table 1). This accords [12].

\subsection{Geochemistry of Abu Darag basaltic dyke}

The chemical analysis of basaltic rocks of both margin and core reveals that the marginal basaltic rocks have high concentrations of $\mathrm{SiO}_{2}, \mathrm{TiO}_{2}, \mathrm{MgO}, \mathrm{Ni}, \mathrm{V}$, and LOI. The contamination from the country sandstone rock as well as the variation in fractionation from the margin to the core play an important part in the variation of some compatible elements giving high concentration of $\mathrm{SiO}_{2}$ in the marginal rocks as well as hydrous minerals filling the vesicles and high abundances of $\mathrm{Ni}, \mathrm{TiO}_{2}$ and $\mathrm{V}$. The chemical weathering has increased LOI, $\mathrm{MgO}$ and $\mathrm{Fe}_{2} \mathrm{O}$ and removed part of $\mathrm{CaO}$ from the marginal part of the basaltic dyke.

\section{Nomenclature, Magma Type and Tectonic Setting}

The plotting of samples on the binary diagram $\mathrm{SiO}_{2}$ versus total alkalis [13] (Fig.5a), all samples fall in the field of basalt. The plotting on the $\mathrm{SiO}_{2}-\mathrm{K}_{2} \mathrm{O}$ diagram of [14] (Fig,5b) shows that, the Mesozoic basalts are fall on the field of alkali rocks while Tertiary basalts fall on the field of sub alkaline except one sample from the top of the basaltic flow of Abu Zenima suggesting some weathering and fractionation of the flow. The plotting on the ternary diagram $\mathrm{TiO}_{2}-\mathrm{P}_{2} \mathrm{O}_{5}$ $\mathrm{K}_{2} \mathrm{O}$ of [15] (Fig5d.) show that, Tertiary basalts are plotted in the oceanic and continental fields, while Mesozoic falls in the continental field .The oceanic affinity of Tertiary basalt may be due to thinner crust of north Egypt).The plot on the ternary $\mathrm{Ti} / 100-\mathrm{Zr}-\mathrm{Y}^{\mathrm{x} 3}$ diagramof [16] (Figs $5 \mathrm{e}$ ) indicate that, both Early Cretaceous and Tertiary basalt fall in the field of within plate. The plot on the binary diagram $\mathrm{Y}$ versus $\mathrm{Cr}$ (Fig.5c) of [17] indicate that the Tertiary and Early Cretaceous basalts fall in the field of within plate, The plotting on the ternary diagram $2 \mathrm{Nb}-\mathrm{Y}-\mathrm{Zr} / 4$ of [18] (Fig.5f) indicate that the Early Cretaceous basalt of Abu Darag fall in the field of within plate alkali basalt field, while Tertiary basalts are plotted in the field of within plate tholeiitic and alkali.
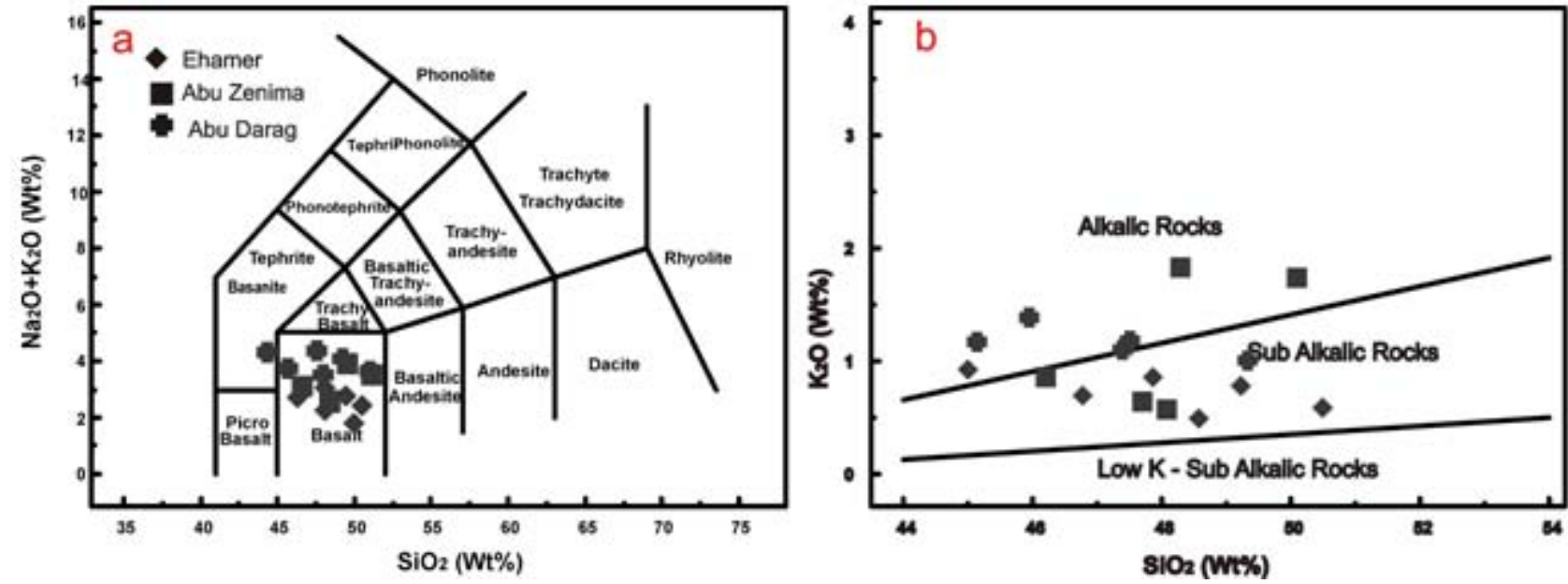

Volume 5 Issue 1 January 2016 

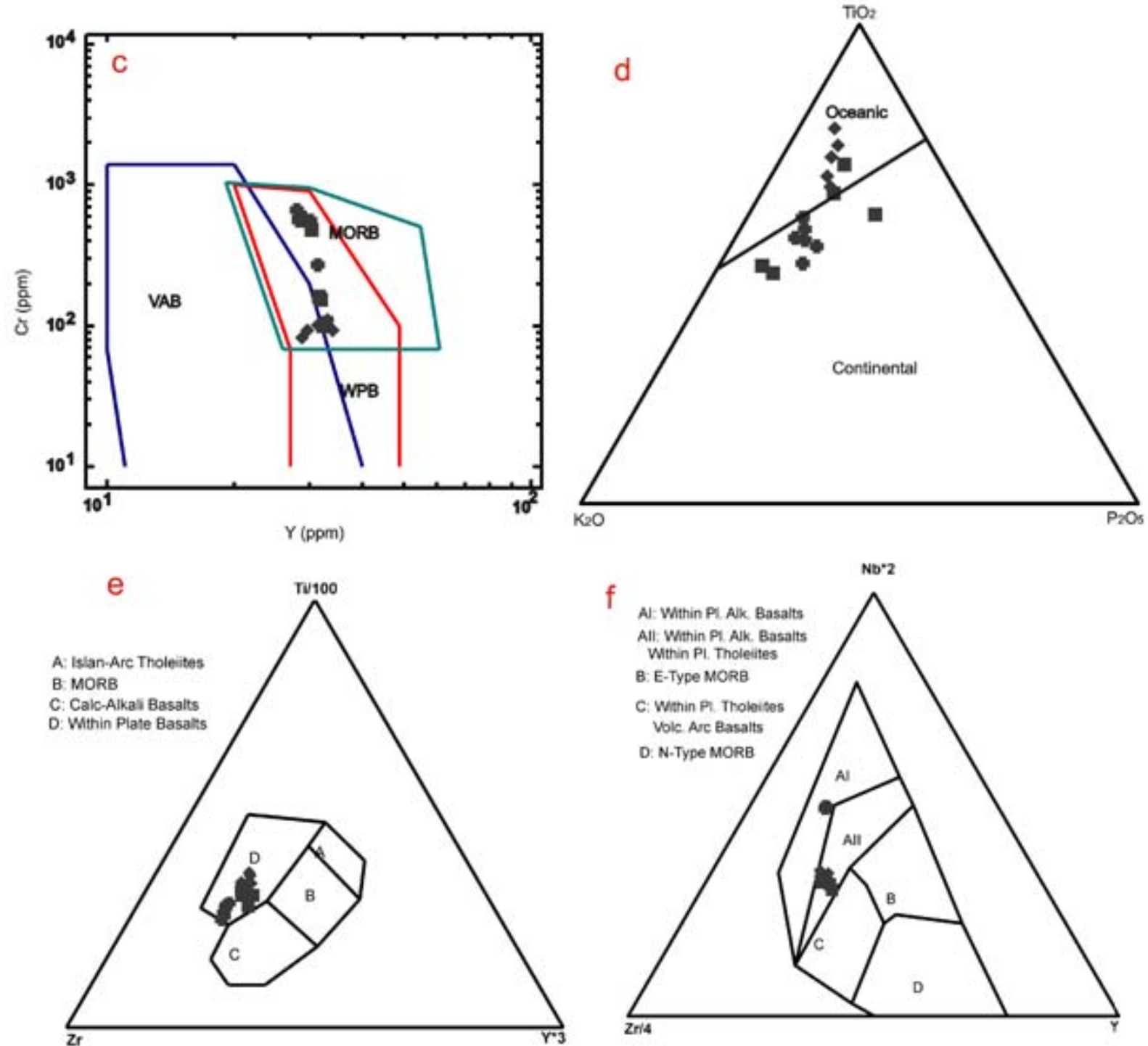

Figure 5: a) $\mathrm{SiO}_{2}$-alkali diagram of Le Bas et al., (1986); b) $\mathrm{SiO}_{2}-\mathrm{k}_{2} \mathrm{O}$ diagram of Middlemost (1975); C) Y-Cr diagram of Pearce (1982); d) $\mathrm{TiO}_{2}-\mathrm{K}_{2} \mathrm{O}-\mathrm{P}_{2} \mathrm{O}_{5}$ diagram of Pearce, et al., 1975); and e) Ti-Zr-Y diagram of Pearce and Can (1973);and f) $\mathrm{Nb}-\mathrm{Zr}-\mathrm{Y}$ diagram of Meschede (1986).

One of the more useful diagrams for identifying the source environment of basalts has been variably called a spider diagram (Fig. 6).From it, the study Tertiary and Early Cretaceous basalts show patterns more or less comparable to that of avg. continental crust of [19] but lower in $\mathrm{Rb}$ and $\mathrm{K}$ and higher in $\mathrm{Nd}, \mathrm{Nb}, \mathrm{Ti}, \mathrm{Y}$, Th and $\mathrm{Tb}$ (Fig 6a). The study basalts are higher in $\mathrm{Th}, \mathrm{Nd}$ and lower in $\mathrm{Sm}$ and $\mathrm{Nb}$ than the avg. oceanic island basalt of [20] (Fig, 6b) and higher more than 10 times in $\mathrm{Rb}, \mathrm{Ba}, \mathrm{Th}, \mathrm{La}, \mathrm{Nb}, \mathrm{Nd}$ and comparable in $\mathrm{Ti}, \mathrm{Yb}, \mathrm{Tb}, \mathrm{Y}$ with respect to MORB of [21] (Fig.6d).Also the study basalts are higher more than 10 times than the condrite composition of [22], (Fig. 6c).

$\mathrm{La} / \mathrm{Sm}$ and $\mathrm{FeO} / \mathrm{MgO}$ of the study Tertiary and Early Cretaceous basalts show negative correlation, suggesting that the sources that are most enriched in incompatible trace elements are depleted in $\mathrm{FeO}$ relative to $\mathrm{MgO}$ [23].
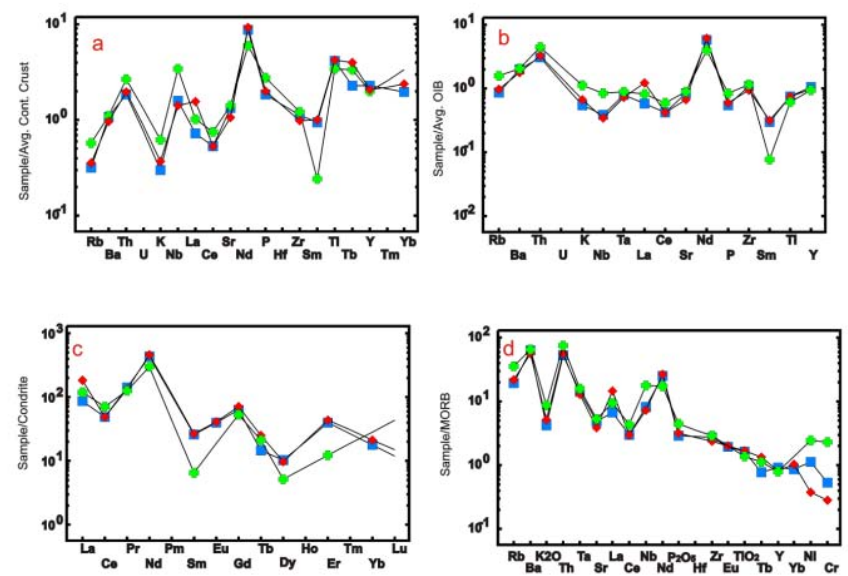

- Abu Darag Ehamer abu Zenima

Figure 6: a) normalized basalt samples to avg. continental crust of Weavor and Tarney (1984); b) samples to avg, ocean island basalt of Sun (1980); c) samples to condrite of Sun and McDonugh (1989), and d) samples to MORB of Bevins et al., (1984) 


\section{International Journal of Science and Research (IJSR) \\ ISSN (Online): 2319-7064}

Index Copernicus Value (2013): 6.14 | Impact Factor (2014): 5.611

\section{Discussion and Conclusions}

Three basaltic occurrences around Gulf of Suez representing two volcanic events. Those near Abu Zenima city (east Gulf of Suez) and Ehamer area (west Gulf of Suez) are of Tertiary age, within plate continental to oceanic type and tholeiitic nature. The third occurrence at Abu Darag area (west Gulf of Suez) is of Mesozoic (Early Cretaceous), within plate continental type and shows alkaline nature. The basalts show some degrees of crustal contamination, crystal fractionation and weathering.

The evolution of the mantle, crustal thickness, depth and degree of partial melting can often be constrained by studying the abundances of high field strength elements $\mathrm{Nb}$, $\mathrm{Zr}, \mathrm{Ti}, \mathrm{Y}$ and $\mathrm{REE}$ and their ratios, $\mathrm{Zr} / \mathrm{Nb}, \mathrm{Zr} / \mathrm{Y}, \mathrm{Y} / \mathrm{Nb}$ and $\mathrm{Zr} / \mathrm{Ti}$ and LREE/HREE [24]. The abundances of $\mathrm{Zr}$ and $\mathrm{Nb}$ are apparently unaffected by sea-water alteration and thus the $\mathrm{Zr} / \mathrm{Nb}$ ratio is potentially a more useful measure of depletion than ratios involving $\mathrm{K}$ and $\mathrm{Rb}$, which are very sensitive to sea-water alteration [25]. If a basalt has only undergone fractional crystallization of olivine, then the abundance of $\mathrm{FeO}$ in the basalt reflects the $\mathrm{FeO} / \mathrm{MgO}$ ratio of the mantle source, the degree of melting, and the pressure at which melting occurs [23].

In terms of high field strength elements and REE abundances and their ratios, some geochemical constraints has been revealed and summarized as follow:

The Tertiary basalts of both Abu Zenima ( top , middle and bottom parts of the basalt flow ) and Ehamer basalts ( plug and dyke ) have $\mathrm{Y} / \mathrm{Nb}, \mathrm{Zr} / \mathrm{Y}, \mathrm{Zr} / \mathrm{Nb}$ ratios are more correlated to each other in spite of contamination, weathering and fractionation. This suggest the same mantle source ;2- The LREE / HREE ratio of Tertiary basalt are similar but lower than that of Abu Darag Early Cretaceous basalt . [26] found that the high field strength element ratios remain unmodified for basalts of the same mantle source;3Abu Darag basalt is enriched in incompatible elements and depleted in $\mathrm{Fe} \mathrm{O}$ relative to $\mathrm{MgO}$ as a result of fractional crystallization of olivine, this accords [23]; 4- The higher abundances of $\mathrm{K}_{2} \mathrm{O}, \mathrm{Na}_{2} \mathrm{O}, \mathrm{Nb}$ and $\mathrm{Zr}$ and higher LREE/HREE ratio of the Early Cretaceous basalt of Abu Darag than those of the Tertiary basalt of Abu Zenima and Ehamer ( Table 1 ) indicate with unravel enriched mantle source and alkali nature of Abu Darag basalt[27]. The continental crust of Egypt is thinner in the northern part [3].This may explain the oceanic affinity of some Tertiary basalt in the northern part of Egypt and may be related to Red Sea opining, 5-The chemical weathering has increased LOI, $\mathrm{MgO}$ and $\mathrm{K}_{2} \mathrm{O}$ and decreased $\mathrm{CaO}$ from the marginal part of Abu Darag basaltic dyke, upper part of Abu Zenima flow and Ehamer dyke, resulting in modified major element compositions. However, the more immobile trace elements remain largely unaltered (Table 1). This accords [12]. 6-The Early Cretaceous basalt of Abu Darag shows a greet crustal contamination than Tertiary basalts of $\mathrm{Abu}$ Zenima and Ehamer as indicated from, a)higher $\mathrm{K}_{2} \mathrm{O} / \mathrm{P}_{2} \mathrm{O}_{5}$ of $\mathrm{Abu}$ Darag basalt( 2.84) than that of Abu Zenima and Ehamer basalts(avg. 2.33) ;b) Lower $\mathrm{Zr} / \mathrm{Nb}$ (5.63) of Abu Darag basalt than that of Tertiary basalt of Abu Zenima and Ehamer ((11.17), c) lower $\mathrm{TiO}_{2} / \mathrm{P}_{2} \mathrm{O}_{5}$ of early Cretaceous basalt (5.09); than that of Tertiary basalt (7.9) ,d) higher Rb and Th of Abu Darag basalt than Abu Zenima and Ehamer Tertiary basalt. This accord [28], 7- Early Cretaceous basalt of Abu Darag is marked by numerous olivine phenocryts in a groundmass of pyroxene, plagioclase and iron oxides, while Tertiary basalt of Abu Zenima and Ehamer has olivine, pyroxene and plagioclase phenocrysts.

\section{References}

[1] W.K. Hamblin, and E.H. Christiansen, “ Earth' Dynamic system," seventh Edition, Prentice-Hall ress .International (UK) Limited, London ,710,1995.

[2] M.Blasy, and A. T. El-Sherbeini "Geochemistry of some Mid-Tertiary basalt around Gulf of Suez, Egypt". Bull. Fac. Sci. Zag. Univ. 18 (2), 173-196. 450, 1996.

[3] R.Said "The Geology of Egypt" second ed. Balkema, A.A., Rotterdam, p. 734, 1990.

[4] M. Blasy. " Petrogenetic implications of Zr,Y,Ti and Nb variations across Abu Darag and Deheisa basaltic dykes, on both sides of Gulf of Suez, Egypt". $5^{\text {th }}$ Conf.On Geochem, Alex. Univ. Egypt. Part 1.189-200, 2000.

[5] A.M. Abdel-Karim. "Petrology of Mesozoic continental basalts from Southwestern Sinai, Egypt". Proceed. $8^{\text {th }}$ Phaner. Develop. Egypt. 163-175, 1992.

[6] G.S. Roufail, M.D .Samuel,M.Y. Meneisy, and H.E. Mousa, "K-Ar age determination of Phanerozoic basaltic rocks in West Central Sinai”, N.Jb. Geol.Palaeont. Mh., 11,683-691, 1989.

[7] H. E.Mousa "Geologic studies and genetic correlation of basaltic rocks in West Central Sinai, " Ph.D thesis, Fac. Sci., Ain Shams University, 1987.

[8] R.L. Rudnick , M. Barth, I.Horny, and W.F. McDonough “ Missing link between contents and depleted mantle, " Science ,287, 278-281,2000.

[9] J.Wade, and B.J. Wood "The Earth,s missing niobium may be in the core," Nature 409(6816), 75-78, 2004.

[10] P.Ottd'Estevou ,J. J.Jarrige, J.C. Icart, C. Montenat, E.Henry J. Cravatte "Observations structuralessur le sector d, Abu Rudeis , Marge orientale du Golfe de Suez, " In C. Montenant ,ed ., Geological studies of the Gulf of Suez, the north -western Red Sea coasts, tectonic and sedimentary evolution of a Neogene rift: Doccuments et Travaux Institutes Geolgique Albert de Lapparant, Paris ,10,75-92, $1987 \mathrm{~b}$.

[11]R, Macdonald, B. Baginski, P.M .Kartashov, D. Zozulya, P. Dziezanowsk, P .Jokubauskas“ Hydrothermal alteration of a columbite-group mineral to a bastnasite $-(\mathrm{Ce})$. Ilmenite -columbite $-(\mathrm{Fe})$ assemblage .interaction with $\mathrm{F}-, \mathrm{CO}_{2}$-rich fluid, ' Miner. Petrol, published online, 2015.

[12]K.Seifert, and D .Dale Brunotte " Geochemistry of weathered mid-ocean ridge basalt and diabase clasts from hole $899 \mathrm{~b}$ in the Iberia abyssal plain1Proceedings of the Ocean Drilling Program," Scientific Results, 149, 1996.

[13] M.J.I. Le Bas, W.LE Maiter. A .Streckisen, and B. Zanettin "A chemical classification of volcanic rocks 
based on the total alkali-silica diagram," J.Petrol. 27(3), 745-750, 1986.

[14]E.A.K. Middlemost "The Basalt Clan," Earth Sci.Rev.11, 337-64, 1975.

[15] J.H. Pearce, B.E. Gorman and, T.C. Birkhett "The $\mathrm{TiO}_{2}$ $\mathrm{K}_{2} \mathrm{O}-\mathrm{P} 2 \mathrm{O}_{5}$ diagram $-\mathrm{A}$ method of discrimination between oceanic and non-oceanic basalts," Earth plant Sci. Let., 24,419,1975.

[16] J.A.Pearce and J.R. Cann "Tectonic setting of basic volcanic rocks determined using trace element analysis," Earth and Planetry Science Letters, 19,290-300, 1973.

[17] J.A. Pearce "Trace element characteristics of lavas from destructive plate boundaries," In S.Thorpe (ed.): Andesites: orogenic andesites and related rocks. 529548, 1982.

[18]M. Mesched "A method of dicrimination between different types of Mid -Oceanic ridge basalts and continental tholeiites with the Nb-Zr- Y diagram," Chem., 56, 207-218, 1986.

[19]B.Weaver, and J. Tarney "Empirical approach to estimating the composition of the continental crust," Nature, 310, 575-577, 1984.

[20] S.S. Sun "Lead isotope study of young volcanic rocks from midocean ridges, ocean islands and island arcs," Philosophical Transactions of the Royal Society of London, series A, 297,409-445, 1980.

[21]R. E. Bevins, B. P, Kokelaar, and P. N. Dunkley "Petrology and geochemistry for lower to middle Ordovician igneous rocks in Wales: A volcanic arc to marginal basin transition," Proc. Geol. Assoc., 95, 337$347,1984$.

[22] S.S .Sun, \& W. F. McDonough "Chemical and isotopic systematics of oceanic basalts: implications for mantle compositions and processes," In: SAUNDERS, A. D. NORRY, M. J. (eds) Magmatisrn in the ocean basins. Geological Society, London, Special Publications 42, 313-345, 1989.

[23] C.H. Langmuir, G.N, Hanson, M. J. O'Hara “An evaluation of major element heterogeneity in the mantle sources of basalts," Philos. Trans. R. Soc. Lond. A 297, 383- 407,1980.

[24] K.C. Condie "High field strength element ratios in Archean basalts: a window to evolving sources of mantle plumes?", 79(3-4),491-504 ,2005.

[25] A. J. Erlank and E. J. D. Kable "The significance of incompatible elements in mid-Atlantic ridge basalts from $45^{\circ} \mathrm{N}$ with particular reference to $\mathrm{Zr} / \mathrm{Nb}$," Contributions to Mineralogy and Petrology , 54(4), 281-291, 1976.

[26]D.P .Cox ,ed. "U.S. Geological Survey-in Geominas mineral resources assessment of Colombia," Ore deposit models: U.S. Geological Survey Open-File Report, 83423, 64 p, 1983a.

[27] Pearce,: "A User's Guide to Basalt Discrimination Diagrams," Geol. Assoc. Canada Short Course, San Diego, USA .Notes 12:79-113, 2014.

[28] C.Manikyamba, S. Ganguly. M. Santosh, A. Saha G.Lakshminarayana "Ageochemistry and petrogenesis of Rajahmundry trap basalts of Krishna-Godavari Basin," India Geoscience Frontiers, 6(6) 791-946, 2015. 